\title{
Nutritional Status, Nutrient Intake and Anthropometric Indices of Children from Agri-business Families, South Africa
}

\author{
Awonke Sonandi*, Zwane Elliot M and Johan A Van Niekerk \\ Centre for Sustainable Agriculture, Rural Development and Extension, University of the Free State, South Africa
}

Submission: November 30, 2017; Published: April 05, 2018

*Corresponding author: Awonke Sonandi, Centre for Sustainable Agriculture, Rural Development and Extension, University of the Free State, Bloemfontein, 9301 South Africa, Email: awonke.sonandi@drdar.gov.za

\begin{abstract}
Food producing families are presumed nutrition secure. This study sought to evaluate the nutritional status of children from historically disadvantaged agri-business families. A purposeful sample comprised of 263 agri-business households, and 302 children aged 5-13 years. A $24 \mathrm{~h}$ recall and food frequency questionnaires were administered along with other questionnaires on the households' socio-economic status and feeding practices, and the caregivers' nutritional knowledge. Food models and Food finder III nutritional software were used to calculate nutrient intake. Statistical Package for Social Sciences, Version 20, was used to perform descriptive, correlation and non-parametric statistical analyses. The households had low food variety and debatably high dietary diversity scores. Generally, nutrient intake varied $(\mathrm{p} \leq 0.05)$ with children's age and gender. Most children had normal weight-to-age (80.14\%), normal height-to-age (90.7\%) and normal body mass index-for-age Z-scores (56.57\%). The children's nutritional status was found to be the function of low farm and non-farm income, low expenditure on food, and low educational status of caregivers. The children did not necessarily have elevated feeding patterns, and nutrient intake. The majority had normal anthropometric indices, although obesity appeared a creeping problem. Nutrition education, diversification and intensification of agri-business practices were highly recommended.
\end{abstract}

Keywords : Nutritional status; Nutrient intake; FVS; DDS; Anthropometric indices, Children

Abbreviations : BMIZ: Body Mass Index-for-age Z score; HAZ: Height-for-age; WAZ: Weight-for-age; ECSECC: Eastern Cape Socio-Economic Consultative Council; FVS: Food Variety Score; DDS: Dietary Diversity Score; FFQ: Food Frequency Questionnaire; RDA: Recommended Dietary Allowance; ANOVA: Analysis of Variance; IFSS: Integrated food security strategy; SD: Standard deviation; SPSS: Statistical package for social sciences; WHO: World Health Organization

\section{Introduction}

The Eastern Cape Province of South Africa is home to 495 042 farming households which are involved in the production of livestock, poultry, grain and food crops, industrial crops, fruit and other commodities [1]. About 95 percent of these farming households constitute those which were disadvantaged by the previous apartheid regime. Since the democratization of South Africa in 1994, the new South African government has introduced numerous food security programmes which sought to improve food security status among previously disadvantaged farming households. These food security programmes included; Ilima/Letsema, Zero-hunger, Fetsa Tlala, and Agricultural Policy Action Plan. Distinctly, these programmes focus on both the production of staple food, and the supply end of the concept of food security. This skewed approach to addressing food insecurity, doesn't sufficiently live up to the official definition of this concept. According to Food and Agriculture Organization [2], people are food secure when at all times, have physical, social and economic access to sufficient, safe and nutritious food that meets their dietary needs and food preferences for an active and healthy life. This official definition of food security carries four components of this concept, namely; food availability, food accessibility, food utilisation and stability [3].

The province's food security programmes have in the past sparked a lot of research interest which tended to focus on low income and survivalist rural farming households and on food availability which is the supply end of the concept of food security [4-10]. Similar local studies on the food utilization pillar of food security which targeted children from previously disadvantaged agri-business households are rare. Instead, children of such households are often presumed nutrition secure or having elevated nutritional status by virtue of being dependants of food producers. One's food security status is no guarantee to achieving good nutritional status. 
Nevertheless, in other parts of the world, the nutrition dimension of food security continues to receives due attention [11]. Research in the nutrition facet covers indicators of nutritional status such as food variety, dietary diversity and nutrient intake [12], and anthropometric parameters [13]. These indicators formed part of the investigation in the current study.

Against the above background, this study sought to evaluate the nutritional status, nutrient intake and anthropometric dimensions of children from agri-business families using a multiple of scientifically proven research methods. It also sought to identify and understand short-comings to achieving good nutritional status, nutrient intake and anthropometric dimensions among the abovementioned children.

\section{Materials and Methods}

\section{Study population and sampling}

The study population was agri-business families who operate and reside in Umzimvubu and Ntabankulu Local Municipalities of Alfred Nzo District Municipality in the Eastern Cape Province, South Africa. Specifically, it targeted previously disadvantaged smallholder agri-business families whose individual or collective annual turnover was between \$11 811 and \$157 480. All families who met this criterion were purposefully selected from a farmer database that was made available by local agricultural extension officers. Subsequent to the exclusion of survivalist farming families (annual turnover less than $\$ 11$ 811) this study included the whole remaining purposeful research sample of 263 agri-business families, and 302 children aged 5-13 years. From each of the 263 farming households, questions that relate to nutritional knowledge, attitudes and feeding and general care of children were directed to caregivers who lived in these households.

\section{Research tools}

Socio-economic and nutrition questionnaires: Upon visiting agri-business households, questionnaires were used to assess the caregivers' socio-economic status, and feeding practices. A $24 \mathrm{~h}$ dietary recall questionnaire was administered twice in weekdays and once in weekends, while a qualitative food frequency questionnaire (FFQ) was administered over a seven-day period. Food models and the internationally acclaimed Food finder III nutritional software of the Medical Research Council of South Africa were used to improve the accuracy of recorded food quantities. Data from the $24 \mathrm{~h}$ dietary recall questionnaire and qualitative $\mathrm{FFQ}$ was used to calculate food variety scores (FVS) and dietary diversity scores (DDS). The former was calculated as the sum of the number of food items consumed by the child over a period of time, while the latter was calculated as the sum of different food groups consumed by the child over a period of time. The following nine food groups were under investigation in this study, namely; cereal, roots and tubers; fleshy foods; dairy foods; legumes and nuts; eggs; vitamin-A rich vegetables and fruits; other fruits and juices; other vegetables; and fats and oils. Quantitative food intakes from the $24 \mathrm{~h}$ dietary recall questionnaire and Food finder III were used to calculate the children's intake of selected macronutrients, minerals and vitamins. Children's nutrient intake was compared with their recommended dietary allowances (RDA) in order to establish whether their nutrient requirements are met in accordance with the Institute of Medicine [14]. The proportion of children whose nutrients intake exceeded two-thirds of the nutrients' RDA was tabulated.

Anthropometric measurements: The researcher and fieldworkers received training from public health workers on measurement of weight and height of the caregivers' children in order to determine anthropometric measurements. Accordingly, a calibrated electronic scale was used to measure weight. All the children were weighed with their shoes and socks being removed, and with their light clothes put on. Two weight readings were taken within the nearest $0.1 \mathrm{~kg}$, and the average of the two readings was recorded if the two readings were different. Height was measured with a stadiometer, with vertical scale of metres and a sliding headpiece, to the nearest $0.1 \mathrm{~cm}$. Children had to put their legs and knees straight together with arms aside, and feet and heels touching together. As with weight, two measurements were taken, and the average recorded if the two measurements were different. Weight and height recordings were captured on Excel, and the following anthropometric measurements determined on WHO Anthro V3.2.2 and Anthro Plus V1.0.4 softwares, namely; weight-for-age Z-scores (WAZ), height-for-age Z-scores(HAZ) and body mass index-for-age Z-scores (BMIZ). WAZ, which is measured in children that are younger than nine years [15] was confined to 146 children aged 5-8 years in this study. MBIZ was calculated as child's weight divide by height squared $(\mathrm{kg} / \mathrm{m} 2)$. The classification of the children's Z-scores of WAZ, HAZ and BMIZ was done in accordance with World Health Organization [16].

\section{Data analysis}

Data was cleaned and statistically analyzed using Statistical Package for Social Sciences (SPSS), Version 20. Descriptive statistics was performed to establish central tendencies, and tests for statistical significance were carried out using analysis of variance (ANOVA). Non-parametric Kruskal-Wallis H tests were used in variables where the assumption of normality was violated, and to elucidate the outcomes of the parametric tests $[17,18]$. Bivariate correlation analysis was conducted to describe relationships between variables. P-values that were less than 0.05 confidence interval were considered nonsignificant, while those that were greater than 0.05 and 0.01 confidence intervals were regarded as significant and nonsignificant, respectively. 
Various measures were put in place to promote validity and reliability of data. These included extensive literature review, use of legitimate and a multiple of research instruments, and a selection of a research sample that is representative of a population to which this study's results are be generalized.

\section{Ethical considerations}

The researcher obtained consent from the caregivers to conduct the study. Their right to anonymity, confidentiality and fair treatment was respected. This study also upheld scientific integrity.

\section{Results}

\section{Socio-economic characteristics}

This sub-section presents the respondents' social characteristics (age, gender, marital status etc.) and economic characteristics (farm and non-farm income, farming activities etc.).

\section{Social characteristics}

Table 1: Demographic Characteristics.

\begin{tabular}{|c|c|c|}
\hline Characteristics & Frequency $(\mathrm{N}=263)$ & Percentage (\%) \\
\hline \multicolumn{3}{|c|}{ Caregivers' Gender } \\
\hline Male & 13 & 5.05 \\
\hline Female & 250 & 94.95 \\
\hline \multicolumn{3}{|c|}{ Caregivers' Role in A Family } \\
\hline Father & 4 & 1.6 \\
\hline Mother & 141 & 53.8 \\
\hline Grand mother & 12 & 4.5 \\
\hline Other & 97 & 36.8 \\
\hline \multicolumn{3}{|c|}{ Caregivers' Educational Qualifications } \\
\hline No education & 41 & 15.6 \\
\hline $\begin{array}{c}\text { Adult basic } \\
\text { education and } \\
\text { training (ABET) }\end{array}$ & 60 & 22.8 \\
\hline Grade $1-7$ & 31 & 11.8 \\
\hline Grade 8-11 & 66 & 25.1 \\
\hline Grade 12 / N3 & 40 & 15.2 \\
\hline $\begin{array}{c}\text { Bachelor's degree/ } \\
\text { diploma }\end{array}$ & 25 & 9.5 \\
\hline
\end{tabular}

The overwhelming majority of the caregivers $(\mathrm{N}=250$, 94.95\%) who were included in this study were women (Table 1). Their marital status was such that most were 'married' ( $N=125,47.5 \%)$, followed by those who were 'never married' $(\mathrm{N}=82,31.2 \%)$ and 'widowed' $(\mathrm{N}=56,21.3 \%)$. Most of the caregivers $(\mathrm{N}=54,20.5 \%)$ fell in the age group of $36-40$ years, followed by those whose age group fell within 46-50 years( $N=36,13.7 \%)$. The number of those who were eligible for government's old age social grants by virtue of having reached 60 years of age was estimated at $55(20.8 \%)$.With respect to education, the majority of caregivers had Grade 8-11 academic qualifications ( $\mathrm{N}=66,25.1 \%)$ (Table 1$)$. Forty-one (15.6\%) had no formal education, while a bachelor's degree/diploma was the highest level of education acquired ( $N=25,9.5 \%)$.

When asked to indicate the number of people who permanently reside in their respective households, most caregivers registered a size of $4-6$ persons $(\mathrm{N}=109,41.4 \%)$, followed by $7-9$ persons ( $N=68,25.9 \%)$. Only 59 (22.4\%) and 27 (10.3\%) households accommodated 1-3 persons and more than 10 persons, respectively. The average size of households in the Eastern Cape Province is 3.9 persons, while that of Alfred Nzo District where this study was undertaken is 3.7 persons [19] (Table 1).

Economic characteristics: Economic characteristics of the agri-business households were described in terms of their non-farm and farm income. With respect to non-farm income, a few caregivers included in this study were employed elsewhere outside their family agri-businesses ( $\mathrm{N}=34,12.9 \%)$. Of these employed caregivers, most were employed on permanent basis $(\mathrm{N}=14,41.2 \%)$, while $32.4 \%$ and $26.5 \%$ were employed on temporary basis and fixed-term contract, respectively. The majority ( $N=143,55.4 \%)$ said they have no employed family members that they permanently lived with. The rest $(\mathrm{N}=115$, $44.6 \%$ ) reported employed family members, ranging from one to three persons per caregiver's household. Non-farm income of households originated from those employed caregivers and their family members with whom they permanently live. Most of the caregivers' households ( $\mathrm{N}=85,32.9 \%)$ earned a monthly non-farm income of between $\$ 78.82$ and $\$ 118.11$, followed by those who earned between $\$ 39.37$ and $\$ 78.74(\mathrm{~N}=55,21.3 \%)$. Some $51(19.8 \%)$ caregivers' households earned more than \$196.85 per month (Table 2).

Table 2: Economic Characteristics.

\begin{tabular}{|c|c|c|}
\hline Characteristics & Frequency (N=263) & Percentage (\%) \\
\hline \multicolumn{2}{|c|}{ Households' Monthly Non-Farm Income } \\
\hline$\$ 39.37-\$ 78.74$ & 55 & 21.3 \\
\hline$\$ 78.82-\$ 118.11$ & 85 & 32.9 \\
\hline$\$ 118.19-\$ 157.48$ & 26 & 10.1 \\
\hline$\$ 157.56-\$ 196.85$ & 41 & 15.9 \\
\hline$>\$ 196.85$ & 51 & 19.8 \\
\hline \multicolumn{2}{|c|}{ Households' Monthly Food Expenditure } \\
\hline$\leq \$ 39.45$ & 19 & 7.2 \\
\hline$\$ 39.49-\$ 55.12$ & 38 & 14.4 \\
\hline$\$ 55.20-\$ 70.87$ & 61 & 23.2 \\
\hline$\$ 70.94-\$ 86.61$ & 39 & 14.8 \\
\hline$\$ 86.69-\$ 94.49$ & 17 & 6.5 \\
\hline$\$ 94.57-\$ 110.24$ & 32 & 12.2 \\
\hline$\$ 110.31-\$ 125.98$ & 11 & 4.2 \\
\hline$\$ 141.82-\$ 157.48$ & 33 & 12.5 \\
\hline$\geq \$ 157.48$ & 13 & 4.9 \\
\hline
\end{tabular}


With respect to the households' monthly expenditure on food, most spent between $\$ 55.20$ and $\$ 70.87$ ( $n=61,23.2 \%$ ). Nineteen (7.2\%) of the caregivers' households spent $\$ 39.37$ or less a month, while 13 (4.9\%) reportedly spent $\$ 157.48$ or more (Table 2). Monthly non-farm income was positively strongly correlated to food expenditure $(r=0.55, \leq 0.01)$ (Table 2$)$.

\section{Feeding practices}

In this sub-section, the results of the agri-business households' feeding practices were presented in terms of breakfast eating patterns, number of meals consumed per day, consumption of vitamin A and C-rich foods, consumption of protein-rich foods, food variety, dietary diversity, food intake and nutrient intake.

Breakfast eating patterns: When requested to quantify frequencies of providing breakfast to their children, about half of the caregivers $(\mathrm{N}=132,50.2 \%)$ said the provision of breakfast is made 'every day of the week'. This group of caregivers was followed by those who reportedly provided breakfast 'four to six times a week' ( $\mathrm{N}=82,31.2 \%$ ), while 23 $(8.7 \%)$ indicated that they 'never' provided breakfast to their children before they go to school (Table 3). The results from the $24 \mathrm{~h}$ dietary recall method showed that the government's school nutrition programme of the Department of Education provided 'late' breakfast between $11 \mathrm{~h} 00$ and $12 \mathrm{~h} 00$ for all school children. This nutrition programme appeared helpful, particularly to children from households ( $N=131 ; 49.8 \%)$ who could not provide breakfast on a daily basis.

Table 3: Households' General Feeding Patterns.

\begin{tabular}{|c|c|c|}
\hline Characteristics & Frequency $(\mathrm{N}=263)$ & Percentage $(\%)$ \\
\hline \multicolumn{3}{|c|}{ Frequency of Provision of Breakfast } \\
\hline Every day & 132 & 50.2 \\
\hline $\begin{array}{l}\text { Four to six times per } \\
\text { week }\end{array}$ & 82 & 31.2 \\
\hline $\begin{array}{l}\text { One to three times } \\
\text { per week }\end{array}$ & 26 & 9.9 \\
\hline Never & 23 & 8.7 \\
\hline \multicolumn{3}{|c|}{$\begin{array}{c}\text { Affordability of Providing Three Meals a Day, and a Snack in } \\
\text { Between }\end{array}$} \\
\hline Can afford & 104 & 39.5 \\
\hline Cannot afford & 159 & 60.5 \\
\hline \multicolumn{3}{|c|}{ Is it difficult to provide different meals a day? } \\
\hline Difficult & 139 & 52.9 \\
\hline Not difficult & 124 & 47.1 \\
\hline
\end{tabular}

Number of meals consumed per day: The eating behaviour and the number of meals that a child can have a day are largely determined by their parents. Indeed, when asked if they 'can afford' providing their children with 'three meals a day and a snack in between', most caregivers ( $N=159 ; 60.5 \%)$ conceded that they 'cannot afford' (Table 3). In line with this response, most caregivers admitted that the provision of such number of meals a day was 'difficult' ( $\mathrm{N}=139,52.9 \%)$, while the rest $(\mathrm{N}=124,47.1 \%)$ said it was 'not difficult' (Table 3$)$. The most cited sources of 'difficulties' in providing children with 'three meals a day and a snack in between' were high cost of food and drought (Table 3-6).

Consumption of Vitamin A and C-rich foods: Investigation into the consumption patterns of vitamin A-rich fruits was limited to ripe mango/mango juice, and apricot/apricot juice. Specifically, the caregivers were asked if over the previous $24 \mathrm{~h}$ period, their children had consumed any of the above fruits. To this end, the majority of caregivers reported that their children had not consumed any of the abovementioned fruits ( $N=203,77.2 \%)$, while only $29(11.0 \%)$ and 26 (9.9\%) indicated that their children had consumed ripe mango/mango juice and apricot fruit/juice, respectively (Table 4).

Table 4: Households' Consumption of Vitamins A and C-rich Foods.

\begin{tabular}{|c|c|c|}
\hline Characteristics & Frequency $(\mathrm{N}=263)$ & Percentage (\%) \\
\hline \multicolumn{3}{|c|}{ Consumption of Vitamin A-Rich Fruits } \\
\hline $\begin{array}{l}\text { Ripe mango/Mango } \\
\text { juice }\end{array}$ & 29 & 11 \\
\hline Apricot fruit/Juice & 26 & 9.9 \\
\hline Both fruit & 0 & 0 \\
\hline $\begin{array}{c}\text { None of the above } \\
\text { fruits }\end{array}$ & 203 & 77.2 \\
\hline Do not know & 5 & 1.9 \\
\hline \multicolumn{3}{|c|}{ Consumption of Vitamin A-Rich Vegetables } \\
\hline Carrot & 169 & 64.3 \\
\hline $\begin{array}{l}\text { Pumpkin/Squash } \\
\text { fruit }\end{array}$ & 51 & 19.4 \\
\hline $\begin{array}{c}\text { None of the above } \\
\text { vegetables }\end{array}$ & 43 & 16.3 \\
\hline \multicolumn{3}{|c|}{ Consumption of Citrus } \\
\hline Every day & 26 & 9.9 \\
\hline Thrice per week & 32 & 12.2 \\
\hline Twice per week & 42 & 16 \\
\hline Once per week & 96 & 36.5 \\
\hline Never & 45 & 17.1 \\
\hline Do not know & 22 & 8.4 \\
\hline
\end{tabular}

With respect to consumption patterns on vitamin A-rich vegetables (carrots and pumpkin/squash fruit), the caregivers were asked to indicate whether over the previous $24 \mathrm{~h}$ period, their children had consumed any of the abovementioned vegetables. In their responses, most caregivers indicated that their children had consumed carrots $(\mathrm{N}=169,64.3 \%)$, followed by pumpkin/squash fruit $(\mathrm{N}=51,19.4 \%)$. On the frequency of consumption of vitamin $\mathrm{C}$-rich citrus, most caregivers said the consumption was 'once per week' $(\mathrm{N}=96,39.5 \%)$, while $42(16.0 \%)$ said it was 'twice per week' (Table 4). Noticeably, responses of a sizeable number of caregivers to this question were 'never' $(\mathrm{N}=45,18.6 \%)$, while a remarkable number responded `do not know' ( $\mathrm{N}=22,9.1 \%)$. 
Consumption of protein-rich foods: Feeding patterns on the following animal protein sources were investigated; organ meat (liver, kidney and heart); flesh meat (beef, mutton, pork and chicken); and fish (fresh fish, canned fish, prawns, mussels, crayfish, crabs and oysters) (Table 5). The caregivers were asked if their children had consumed any of the abovementioned protein-rich foods over the past $24 \mathrm{~h}$. With respect to 'organ meat', a fairly equal number of caregivers responded that their children had consumed 'organ meat' $(\mathrm{N}=123,46.8 \%)$, while others said they had consumed 'none of the organ meat' ( $N=122,46.4 \%)$. Noticeably, liver was the most popular 'organ meat', followed by kidney and heart.

Table 5: Households' consumption of protein-rich foods.

\begin{tabular}{|c|c|c|}
\hline Characteristics & Frequency (N=263) & Percentage (\%) \\
\hline \multicolumn{3}{|c|}{ Organ Meat Consumed } \\
\hline Liver & 123 & 46.8 \\
\hline Kidney & 6 & 2.3 \\
\hline Heart & 12 & 4.6 \\
\hline None of the above & 122 & 46.4 \\
\hline \multicolumn{3}{|c|}{ Flesh Meat Consumed } \\
\hline Mutton & 11 & 4.2 \\
\hline Beef & 4 & 1.5 \\
\hline Pork & 5 & 1.9 \\
\hline Chicken & 160 & 60.8 \\
\hline None of the above & 83 & 31.6 \\
\hline \multicolumn{2}{|c|}{ Fish Consumed } \\
\hline Fresh fish & 13 & 4.9 \\
\hline Canned fish & 161 & 61.2 \\
\hline Sea food & 0 & 33.8 \\
\hline No fish consumed & 89 & \\
\hline
\end{tabular}

On 'flesh meat', the majority of caregivers reported that their children had consumed 'chicken' ( $N=160,60.8 \%)$, while a sizeable number $(\mathrm{N}=83,31.6 \%)$ said their children had consumed 'none of the flesh meat' (Table 5). 'Beef' $(\mathrm{N}=4$, $1.5 \%)$ and 'pork' $(\mathrm{N}=5,1.9 \%)$ consumption was restricted to very few households. Regarding 'fish', only the consumption of 'canned fish' $(\mathrm{N}=161,61.2 \%)$ and 'fresh fish' $(\mathrm{N}=13,4.9)$ were registered by the caregivers. No consumption of seafood (prawns, mussels, crayfish, crabs, oysters) was reported.

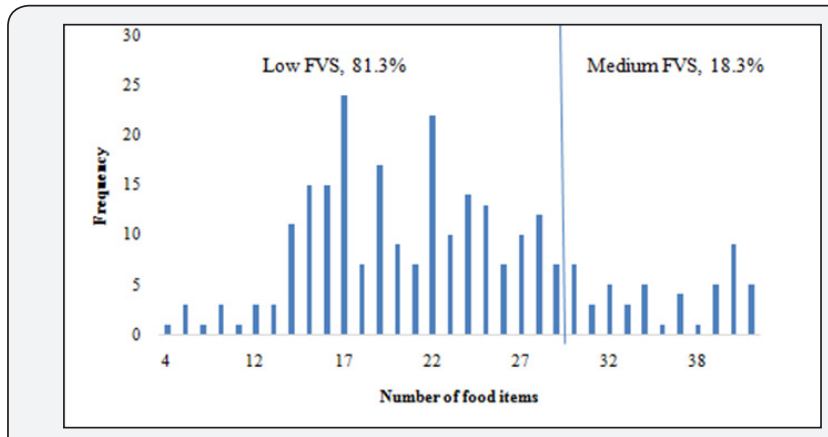

Figure 1: Distribution of food variety scores from the caregivers households using a $24 \mathrm{~h}$ dietary recall method.
Food variety and dietary diversity: Recording of the agribusiness households' feeding practices led to generation of FVS and DDS using the $24 \mathrm{~h}$ dietary recall method and qualitative FFQ. The average FVS from the $24 \mathrm{~h}$ dietary recall method for the 263 investigated households was low at $23.43 \pm 10.65$ (Table 4). Most of the caregivers' households ( $N=215 ; 81.7 \%)$ had a low FVS, followed by those with a medium FVS (N $=48 ; 18.3 \%)$. None of the households had a high FVS category (Figure $1 \& 2$ ). These results were echoed by those from the qualitative FFQ where households' FVS was also low at $25.51 \pm 8.32$.

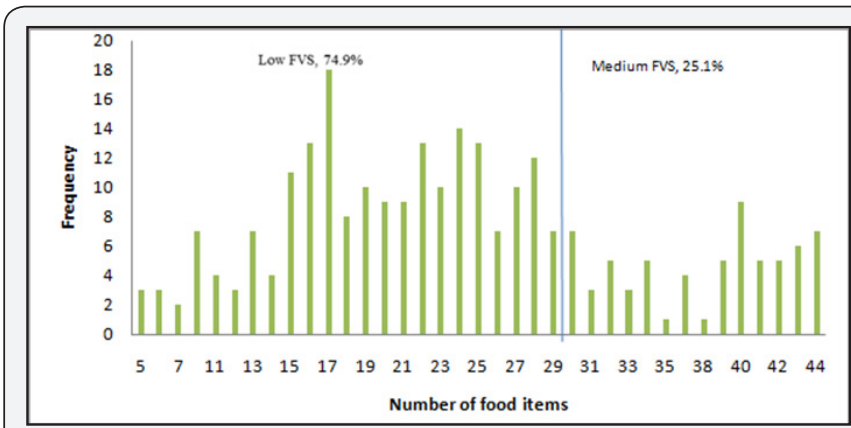

Figure 2 : Distribution of food variety scores from the caregivers' households using a qualitative FFQ.

Regarding dietary diversity, the mean DDS from the $24 \mathrm{~h}$ dietary recall method and qualitative $\mathrm{FFQ}$ were $7.82 \pm 3.20$ and $8.12 \pm 3.54$, respectively. These results were indicative of high DDS $[20,21]$. From the $24 \mathrm{~h}$ dietary recall method, most the caregivers' households $(\mathrm{N}=88 ; 33.5 \%)$ consumed foods from eight food groups, followed by those $(\mathrm{N}=71 ; 27.0 \%)$ who consumed foods from all nine foods groups. Three food groups was the lowest number consumed ( $\mathrm{N}=5 ; 1.9 \%)$. The majority of the caregivers' households $(\mathrm{N}=184 ; 70 \%)$ had high DDS (Figure 3), followed by those with medium DDS (37.2\%) and low DDS (8.2\%). Results from the qualitative FFQ also followed a similar trend as shown in Figure 3 .

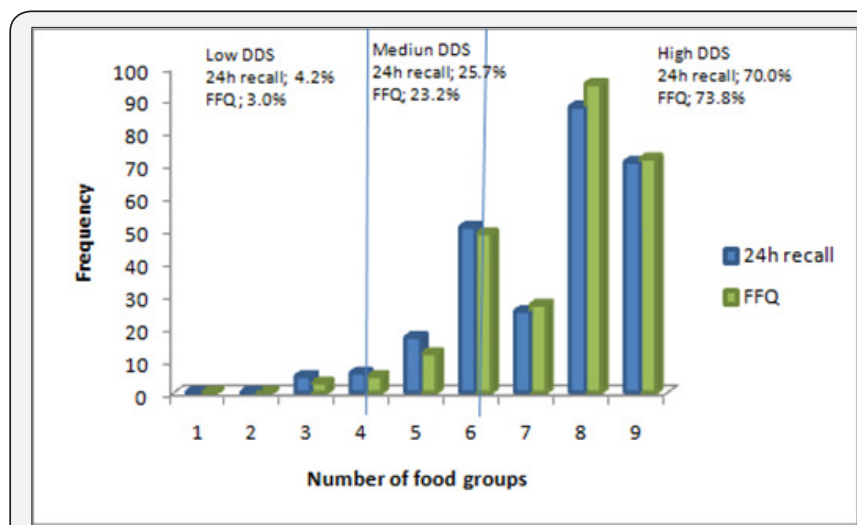

Figure 3 : Distribution of dietary diversity scores from the caregivers' households using both the $24 \mathrm{~h}$ dietary recall method and qualitative FFQ.

Table 7 presents a summary of top 20 most consumed food items by the caregivers' children during the 3-day 24h dietary recall method and the seven-day qualitative FFQ. Noticeably, the carbohydrates-rich food items from the 'cereal, roots and tubers' group dominated the top 10 most consumed foods. 
From the 'flesh' and 'dairy products' groups, only canned fish and chickens, and fresh milk and sour milk, respectively, appeared in the list of top 20 most consumed foods items. Only carrots and spinach from the vitamin A-rich vegetables and fruits' group, and cabbage and onion from the 'other vegetables' group appeared in the list presented in Table 7, while sunflower oil represented the 'fats and oils' group. Food groups whose food items did not feature in the list in question were 'eggs', 'legumes and nuts', and 'other fruits and juices' groups.

This study also found that consumed quantities of food items varied widely within and between households, largely due to the varying socio-economic profiles of the caregivers' households. Consumed quantities of food items from other food groups were rather low (e.g. dairy products, vegetables, and flesh foods). Again, this appeared a function of socioeconomic characteristics of the caregivers' households, which have been discussed earlier in this paper.

Nutrient intake: Food consumption patterns, FVS and DDS that have been discussed in the previous sections of this paper are directly linked to nutrient intake which is under discussion in the current section $[22,23]$. The proportion of children whose median nutrients intake exceeded $67 \%$ of the nutrients' RDA was presented in Table 8. Also indicated in Table 8 are those nutrients whose intake by less than $50 \%$ of children exceeded the $67 \%$ cut-off point of the nutrients' RDA. The intake of such nutrients was regarded as low, but moderate/high for those nutrients whose intake by more than $50 \%$ of children exceeded this $67 \%$ cut-off point.

Differences in nutrient intake between male and female children were highly significant $(\mathrm{p} \leq 0.01)$ in nutrients with the exception in calcium where these differences were significant $(p \leq 0.05)$. To this end, less than half $(50 \%)$ of male and female children had nutrients intake that were above the $67 \%$ threshold in nine and fourteen nutrients, respectively (Table 8). There were also highly significant $(\mathrm{p} \leq 0.01)$ differences in nutrient intake among children aged 5-8 years and 9-13 years, with the exception in vitamin $\mathrm{K}$ where these differences were non-significant $(\mathrm{p} \geq 0.05)$.That is, less than half $(50 \%)$ of younger (5-8 years) and older children (9-13 years) had nutrients intake that were above the $67 \%$ cut-off point in five and eighteen nutrients, respectively (Table 8).

Among macro-nutrients, the intake of protein and carbohydrates, in particular, exceeded $67 \%$ of the nutrients RDAs among the overwhelming majority of children. The moderate/high intake of protein appeared to have been supported by consumption of the two main protein sources, namely; canned fish and chicken (Table 7), while a similar intake of carbohydrates was due to high FVS within the 'cereal, roots and tubers' food group (Table 6). To the contrary, the intake of dietary fibre was low as it exceeded $67 \%$ of this nutrient's RDA in less than half of female children aged 5-8 years and children aged 9-13 years. Low dietary fibre intake was in part caused by low consumption of fibre-rich fruit and vegetables, and virtually no consumption of cereals.

Table 6: Food variety scores within food groups.

\begin{tabular}{|c|c|c|c|c|}
\hline Qualitative FFQ & \multicolumn{2}{|c|}{$\begin{array}{c}\text { 24h dietary } \\
\text { recall method }\end{array}$} & \multicolumn{2}{c|}{ Qualitative FFQ } \\
\hline & Mean & SD & Mean & SD \\
\hline Cereal, roots and tubers & 5.05 & 0.89 & 5.26 & 1.01 \\
\hline Fleshy foods & 3.22 & 1.08 & 3.34 & 0.92 \\
\hline Dairy products & 1.97 & 1.14 & 2.3 & 0.84 \\
\hline Legumes and nuts & 1 & 0.58 & 1.08 & 0.63 \\
\hline Eggs & 0.38 & 0.49 & 0.31 & 0.21 \\
\hline Vitamin A-rich vegetables \\
and fruits & 3.06 & 1.2 & 3.8 & 0.97 \\
\hline Other fruits and juices & 2.85 & 1.93 & 2.8 & 1.02 \\
\hline Other vegetables & 4.03 & 2.48 & 4.59 & 1.98 \\
\hline Fats and oils & 1.86 & 0.86 & 2.03 & 0.74 \\
\hline Total Food Items & 23.43 & & 25.51 & \\
\hline
\end{tabular}

Table 7: The top 20 most consumed food items measured by the $24 \mathrm{~h}$ dietary recall and qualitative FFQ.

\begin{tabular}{|c|c|c|c|c|}
\hline \multirow[b]{2}{*}{ Rank } & \multicolumn{2}{|c|}{ 24h Dietary Recall Method } & \multicolumn{2}{|c|}{ Qualitative FFQ } \\
\hline & Food Item & $\begin{array}{c}\text { Mean Food Intake, g/ } \\
\text { Person/Day }\end{array}$ & Rank & Food Item \\
\hline 1 & Maize meal soft porridge & $99.23 \pm 74.56$ & 1 & White sugar \\
\hline 2 & Instant tea & $182.14 \pm 131.38$ & 2 & Maize meal stiff porridge \\
\hline 3 & White sugar & $19.99 \pm 7.05$ & 3 & Sweetened cold drink \\
\hline 4 & Maize meal stiff porridge & $123.49 \pm 72.79$ & 4 & Brown bread/rolls \\
\hline 5 & Brown bread/Rolls & $27.58 \pm 30.81$ & 5 & Maize meal soft porridge \\
\hline 6 & Amarhewu & $176.78 \pm 174.66$ & 6 & Instant tea \\
\hline 7 & Crumbed maize meal & $107.67 \pm 105.07$ & 7 & Amarhewu \\
\hline 8 & Fresh milk & $21.85 \pm 26.34$ & 8 & Coffee creamer \\
\hline
\end{tabular}


Nutrition \& Food Science International Journal

\begin{tabular}{|c|c|c|c|c|}
\hline 9 & Potatoes & $21.38 \pm 14.34$ & 9 & Crumbed maize meal \\
\hline 10 & Maize samp & $156.63 \pm 139.91$ & 10 & Fresh milk \\
\hline 11 & Rice & $64.86 \pm 36.03$ & 11 & Rice \\
\hline 12 & Sour milk & $128.57 \pm 118.77$ & 12 & Potatoes \\
\hline 13 & Carrot & $14.28 \pm 10.94$ & 13 & Sunflower oil \\
\hline 14 & Baked bread, homemade & $49.16 \pm 50.43$ & 14 & Sour milk \\
\hline 15 & Cabbage & $10.64 \pm 12.47$ & 15 & Carrot \\
\hline 16 & Spinash & $10.17 \pm 14.89$ & 17 & Baked bread, homemade \\
\hline 17 & Onion & $8.78 \pm 11.74$ & 18 & Cabbage \\
\hline 18 & Sunflower oil & $23.85 \pm 32.99$ & 19 & Canned fish \\
\hline 20 & Canned fish & $13.66 \pm 17.56$ & 20 & Spinach \\
\hline
\end{tabular}

The intake of minerals was moderate/high on four out of six minerals that were under investigation in this study. These minerals were iron, zinc, magnesium and phosphorus. Their intake exceeded $67 \%$ of RDA in over half of the 302 children who were included in this study, irrespective of their age or gender. However, the same could not be said for calcium and selenium, because less than half of the children exceeded the threshold of $67 \%$ of these nutrients' RDA.
Among vitamins, moderate/high intake was recorded on eleven out of twelve vitamins that were investigated. These vitamins were, namely; vitamin A, vitamin B6, vitamin B12, vitamin $\mathrm{C}$, vitamin $\mathrm{E}$, vitamin $\mathrm{K}$, thiamine, riboflavin, niacin, pantothenic acid and biotin. The intake of these vitamins exceeded $67 \%$ of their RDA in more than $50 \%$ of the 302 children understudy, irrespective of age or gender. The contrary held for folate where its intake was in excess of $67 \%$ of its RDA in less than $50 \%$ of the studied 302 children (Table 8).

Table 8: Proportion of children aged 5-13 years whose baseline nutrients intake exceeded $67 \%$ of the nutrients' RDA.

\begin{tabular}{|c|c|c|c|c|}
\hline \multirow[t]{3}{*}{ Nutrient } & \multicolumn{2}{|c|}{ Gender and age group } & & \\
\hline & \multicolumn{2}{|c|}{ No. of Children Aged 5-8 Years, N(\%) } & \multicolumn{2}{|c|}{ No. of Children Aged 9-13 years, N(\%) } \\
\hline & Male & Female & Male & Female \\
\hline Carbohydrates & $95(100)$ & $51(100)$ & $51(100)$ & $84(100)$ \\
\hline Protein & 95(100) & $51(100)$ & $51(95.4)$ & $77(91.7)$ \\
\hline Total fibre & $65(68.4)$ & $15(29.4)^{<50 \%}$ & $15(13.9)^{<50 \%}$ & $20(23.8)^{<50 \%}$ \\
\hline Calcium & $86(90.5)$ & $25(49.0)^{<50 \%}$ & $25(30.8)^{<50 \%}$ & $14(16.7)^{<50 \%}$ \\
\hline Iron & $95(100)$ & $45(88.2)$ & $45(90.8)$ & $74(88.1)$ \\
\hline Magnesium & $95(100)$ & $51(100)$ & $51(70.8)$ & $69(82.1)$ \\
\hline Phosphorus & $95(100)$ & $51(100)$ & $51(53.9)$ & $17(20.2)^{<50 \%}$ \\
\hline Zinc & $95(100)$ & $51(100)$ & $51(66.2)$ & $29(34.5)^{<50 \%}$ \\
\hline Selenium & $71(74.7)$ & $28(54.9)$ & $28(18.5)^{<50 \%}$ & $13(15.5)^{<50 \%}$ \\
\hline Vitamin A & $95(100)$ & $38(74.5)$ & $38(63.1)$ & $58(69.1)$ \\
\hline Vitamin B6 & $95(100)$ & $44(86.3)$ & $44(49.2)^{<50 \%}$ & $22(26.2)^{<50 \%}$ \\
\hline Vitamin B12 & $95(100)$ & $45(88.2)$ & $45(84.6)$ & $74(88.1)$ \\
\hline Vitamin C & $86(90.5)$ & $34(66.7)$ & $34(23.1)^{<50 \%}$ & $29(34.5)^{<50 \%}$ \\
\hline Vitamin E & 95(100) & $41(80.4)$ & $41(64.6)$ & $39(46.4)^{<50 \%}$ \\
\hline Vitamin $\mathrm{K}$ & -93.68 & $28(54.9)$ & $28(27.7)^{<50 \%}$ & $57(67.9)$ \\
\hline Thiamin & $95(100)$ & $51(100)$ & $51(90.8)$ & $67(79.8)$ \\
\hline Riboflavin & $95(100)$ & $51(100)$ & $51(64.62$ & $77(91.7)$ \\
\hline Niacin & $95(100)$ & $51(100)$ & $51(81.5)$ & $67(79.7)$ \\
\hline Folate & $80(84.2)$ & $25(49)^{<50 \%}$ & $25(30.8)^{<50 \%}$ & $22(26.2)^{<50 \%}$ \\
\hline Pantothenic acid & $92(96.8)$ & $37(72.6)$ & $37(58.5)$ & $46(54.8)$ \\
\hline Biotin & $95(100)$ & $44(86.3)$ & $44(80)$ & $56(66.7)[1]$ \\
\hline
\end{tabular}

$<50 \% \quad$ - less than half of the gender or age group of children had nutrients intake that exceeded $67 \%$ of nutrients' RDA. 


\section{Anthropometric parameters}

The investigated anthropometric parameters which are under discussion in this sub-section where namely; weightfor-age (WAZ), height-for-age (HAZ) and body mass index-for age (BMIZ).

WAZ, HAZ and BMIZ: As indicated earlier, the measurement of WAZ was limited only to 146 children of 5-8 years of age. Of these children, the majority $(80.14 \%)$ had normal WAZ (<-1SD to <0SD), while the remaining minority $(19.86 \%)$ were underweight ( $\geq-3$ SD to $<-2$ SD) [Table 9]. The prevalence of underweight was higher among male children than in their female counterparts $(\mathrm{p} \leq 0.05)$. Of the 302 children who were subjected to HAZ measurement, the overwhelming majority $(90.70 \%)$ had normal HAZ (>-1SD to +3SD). The rest were stunting ( $\leq-2 \mathrm{SD})$, particularly female children $(\mathrm{p} \geq 0.05)$. The measurement of BMIZ was also extended to all 302 children. Over half $(56.57 \%)$ of children included in this study had normal BMIZ ( $>-2$ SD to $<+1 S D$ ), and a very small proportion $(0.92 \%)$ was wasting (<-2SD to $>-3 \mathrm{SD}$ ). Of concern was a creeping problem of over-nutrition. To this end, $36.39 \%$ of children were at risk of overweight $(>+1 \mathrm{SD}$ to $<+2 \mathrm{SD})$, while $6 \%$ and $8 \%$ were overweight $(>+2$ SD to $<+3$ SD) and obese $(>+3 S D)$, respectively. Noticeably, female children were heavier than their male counterparts of the same age $(p \geq 0.05)$. The caregivers were given an opportunity to visually appraise the body condition of their children in a scale of underweight, normal weight, overweight and obese. In their responses, most of the caregivers rated the weight of their children as normal ( $N=221,84 \%$ ), followed by those who rated them underweight $(\mathrm{N}=29,11 \%)$, overweight $(\mathrm{N}=1,0.4 \%)$ and obese $(\mathrm{N}=12,4.6 \%)$ (Table 9).

Table 9: Summary of anthropometric characteristics of the children aged 5-13 years.

\begin{tabular}{|c|c|c|c|c|}
\hline Classification [1] & Z-score & Gender Male, N (\%) & Female,N (\%) & Total \\
\hline \multicolumn{5}{|c|}{ WAZ $(N=146)$} \\
\hline Severely under weight & $<-3 S D$ & 0 & 0 & 0 \\
\hline Underweight & $\geq-3 S D$ to $<-2 S D$ & $17(17.71 \%)$ & $12(24.00 \%)$ & $29(19.86 \%)$ \\
\hline Normal WAZ & $<-1 S D$ to $<0 S D$ & $79(82.29 \%)$ & $38(76.00 \%)$ & $117(80.14 \%)$ \\
\hline \multicolumn{5}{|l|}{ HAZ $(\mathrm{N}=302)$} \\
\hline Severely stunting & $<-3 S D$ & 0 & 0 & 0 \\
\hline Stunting & $\leq-2 S D$ & $13(7.34 \%)$ & $17(11.33 \%)$ & $30(9.30 \%)$ \\
\hline Normal HAZ & $<-1 S D$ to $+3 S D$ & $164(92.66 \%)$ & $133(88.67 \%)$ & $297(90.7 \%)$ \\
\hline \multicolumn{5}{|c|}{ BMIZ (N=302) } \\
\hline Severely wasting & $<-3 S D$ & 0 & 0 & 0 \\
\hline Wasting & $<-2 S D$ to $>-3 S D$ & $2(1.13 \%)$ & $1(0.67 \%)$ & $3(0.92 \%)$ \\
\hline Normal BMIZ & $>-2 \mathrm{SD}$ to $<+1 \mathrm{SD}$ & $117(66.10 \%)$ & $68(45.33 \%)$ & $185(56.57 \%)$ \\
\hline Risk of overweight & $>+1 \mathrm{SD}$ to $<+2 \mathrm{SD}$ & $52(29.38 \%)$ & $67(44.67 \%)$ & $119(36.39 \%)$ \\
\hline Overweight & $>+2 \mathrm{SD}$ to $<+3 \mathrm{SD}$ & $2(1.13 \%)$ & $6(4.00 \%)$ & $8(2.45 \%)$ \\
\hline Obese & $>+3 \mathrm{DS}$ & $4(2.26 \%)$ & $8(5.33 \%)$ & $12(3.67 \%)$ \\
\hline
\end{tabular}

[1] WAZ - Weight for age

HAZ - Height for Age

BMIZ - Body Mass Index for age- Z score

SD - Standard Deviation

\section{Factors affecting anthropometric parameters}

Hypothetical tests were conducted on key factors that were deemed influential in the children's anthropometric parameters, namely; WAZ, HAZ and BMIZ. These key factors were farm and non-farm income, food expenditure, the caregivers' level of education and breakfast eating patterns. As shown in Table 10, all these key factors, with the exception of breakfast eating patterns, had an influence $(\mathrm{p} \leq 0.01)$ on the children's WAZ, HAZ and BMIZ. The influence of breakfast patterns on the children's anthropometric parameters was rather non-significant $(\mathrm{p} \geq 0.05)$.

\section{Discussion}

The results from this study showed that the agri-business families under investigated had rather modest feeding practices that were characterized with skipping of meals and provision of a limited variety of meals. This observation was clear right from their provision of the first meal of the day-breakfast. Half of the caregivers could not provide their children with breakfast before they go to school or church. Skipping breakfast is not a good feeding practice, because of its association with poor performance of children at school and numerous health risks such as reduction of short memory [24], 
reduction of metabolism and increased cholesterol and insulin levels [25] depletion of energy and increased risk of type 2 diabetes [26].

Breakfast is one of many meals that were skipped by the caregivers' children understudy. Ideally, children aged 5-13 should have at least three meals a day and a snack in between [27]. However, in this study, only 39.5\% of the caregivers' households could afford the above prescribed number of meals. Equally of concern is the quality of consumed meals in the face of the revelation that over half of the caregivers' households found it difficult to provide a variety of meals to their children. A wide variety of meals is likely to provide a wide range of nutrients that are necessary for a child's good nutritional status, health and performance at school. This view is widely held by many in the literature [28].

Table 10: Summary of results of Kruskal-Wallis $\mathrm{H}$ tests on the effect of farm and non-farm income, food expenditure, caregivers' level of education, and breakfast eating patterns on anthropometric parameters.

\begin{tabular}{|c|c|c|c|c|c|c|}
\hline \multirow[t]{2}{*}{$\begin{array}{l}\text { Anthropometric } \\
\text { Parameters }\end{array}$} & \multicolumn{2}{|c|}{ Monthly Non-Farm Income } & & \multicolumn{3}{|c|}{ Monthly Food Expenditure } \\
\hline & df & Chi-square & Asymp. Sig. & df & Chi-square & Asymp. Sig \\
\hline WAZ & 4 & 44.23 & $0.000^{* *}$ & 8 & 40.12 & $0.000^{* *}$ \\
\hline HAZ & 4 & 43.18 & $0.000^{* *}$ & 8 & 43.91 & $0.000^{* *}$ \\
\hline BMIZ & 4 & 42.82 & $0.000^{* *}$ & 8 & 46.08 & $0.000^{* *}$ \\
\hline \multicolumn{3}{|c|}{ Monthly farm income } & & \multicolumn{3}{|c|}{ Level of education } \\
\hline & $\mathrm{df}$ & Chi-square & Asymp. Sig. & df & Chi-square & Asymp. Sig. \\
\hline WAZ & 7 & 74.83 & $0.027^{*}$ & 5 & 14.27 & $0.010^{*}$ \\
\hline HAZ & 7 & 71.21 & $0.038^{*}$ & 5 & 13.42 & $0.015^{*}$ \\
\hline BMIZ & 7 & 69.82 & $0.045^{*}$ & 5 & 12.18 & $0.021^{*}$ \\
\hline \multicolumn{7}{|c|}{ Breakfast Eating Patterns } \\
\hline & df & Chi-square & Asymp. Sig. & & & \\
\hline WAZ & 1 & 1.93 & 0.32 & & & \\
\hline HAZ & 1 & 2.4 & 0.43 & & & \\
\hline BMIZ & 1 & 1.6 & 0.2 & & & \\
\hline
\end{tabular}

The low consumption of vitamin C-rich citrus was remarkable (Table 4). Part of this sparingly low consumption may have been due to limited availability and the commensurately higher price of citrus, which in turn may have been caused by the citrus post-harvest period (September) at which data collection for this study was started. To the contrary, the widespread consumption of vitamin A-rich vegetables (carrot and pump/squash fruit) was commendable. By virtue of being a dark leafy vegetable, the high consumption of spinach and liver (Table 5) might have resulted in a good intake of vitamin A.

Noticeably, the 'fleshy food' group had a wider variety of food items $(n=10)$, than the 'cereal, roots and tubers' group ( $\mathrm{N}=7)$, yet fewer affordable food items from this group were consumed. The low FVSs of 3.22 and 3.34 from the $24 \mathrm{~h}$ dietary recall method and qualitative $\mathrm{FFQ}$, respectively, bears testimony to this claim. Canned fish was consumed the
The caregivers' inabilities in providing a variety of meals to their children is reflected on their households' low FVS. Most the caregivers' households provided meals that were dominated by carbohydrates-rich maize products such as stiff porridge, crumbed maize meal, samp and amarhewu, and wheat-based products such as steamed bread and baked bread. It was, therefore, not surprising that in this study the 'cereal, roots and tubers' food group had the highest FVS. On the other hand, it is commendable that most of the caregivers' households had a conservatively high DDS. This high DDS came as a result of consumption of few food items on a wide range of the nine food groups. This eating pattern is unlikely to lead to adequate nutrient intake and good nutritional status due to exclusion of critically important nutrients in the feeding menu(Table 10). most, followed by chicken, while mutton, beef and pork were consumed in very few caregivers' households. It appeared that this feeding pattern was primarily driven by food costs. In the area where this study was undertaken, the average retail price of a $400 \mathrm{~g}$ canned fish was $\$ 1.18$, while frozen chicken costs $\$ 2.91 / \mathrm{kg}$. Mutton, beef and pork cost $\$ 5.64 / \mathrm{kg}, \$ 5.40 / \mathrm{kg}$ and $\$ 4.89 / \mathrm{kg}$, respectively.

When faced with high costs of 'fleshy foods', the feeding behavior of the population understudy did not seem to favorably accommodate alternative cheaper protein sources such as legumes. The FVSs for the 'legumes and nuts' food group were 0.96 and 1.08 from the $24 \mathrm{~h}$ dietary recall method and qualitative FFQ, respectively. Dried beans which are often prepared with maize samp were not in the top 20 most consumed food items, while dried peas were consumed in very few households $(\mathrm{N}=9 ; 3.57 \%)$. Soya and lentils were not consumed. This situation presented itself as an area for 
nutrition awareness and nutrition education. The agricultural extension personnel are best placed to perform this function.

A wide range of fruit, which could have provided a good source of minerals and vitamins, was either rarely consumed or not consumed in many households. Apples and citrus were two most consumed fruits, but their consumption was limited to approximately half of the 263 households that were included in this study. Consumption of bananas was expected to be high by virtue of the proximity of the studied population and local retail shops to banana plantations of the province of KwaZuluNatal. Banana consumption was reported in only $28.57 \%$ of the caregivers' households. It appeared that physical availability of this food item was not a problem, but its financial accessibility [29].

FVS and DDS which are indicative of the farming households' nutritional status were influenced by a number of socioeconomic factors. First and foremost, the caregivers' level of education had a significant influence on FVS $(\mathrm{p} \leq 0.05)$ than on DDS ( $p \geq 0.05$ ). Probably, higher level of education of caregivers played a critical role in exposing them to good nutritional and caring practices for their children. Similar observations were also made by some authors $[30,31]$, while others could not find a relationship between parents' level of education and their children's nutritional status [32]. Further analysis of results showed that the caregivers' level of education had a significant effect $(p \leq 0.05)$ on their households' monthly non-farm income and expenditure on food. The monthly non-farm income was positively strongly correlated to food expenditure $(r=0.55$, $\mathrm{p}<0.01)$. In turn, food expenditure had a significant influence on FVS ( $r=0.672 ; \mathrm{p}<0.01)$ and DDS ( $\mathrm{r}=0.322$; $\mathrm{p}<0.01)$.

These findings on the economic variables (income and food expenditure) are similar to those reported in a survey that was conducted by ECSECC [19] at Alfred Nzo District. The survey found that most of the monthly expenditure was used to acquire non-durable goods like food, while very little was used to buy either durable or semi-durable goods. For example, in 2013 from a total household income of $\$ 811$ million, \$724 million was used in household expenditure. ECSECC [19] concluded that this elevated household expenditure was symptomatic of poverty in the district, as high expenditure on non-durable goods does very little contribution to wealth creation.

With respect to farming activities of the agri-businesses, the results from this study showed that income from these activities was not sufficient to allow easy financial access to a wide range of food items. Their farm produce may not have been sufficient either as evidenced in the low FVS and debatably high DDS. These findings echoed those made earlier by other authors whose work included the same geographical area of Alfred Nzo District Municipality [33]. They found that nonfarming families were more food secure than their farming counterparts, because instead of relying on food production, they purchase a wide variety of food items.
Generally, the nutrient intake of children from agribusiness families was reflective of a rather modest feeding behaviour. This was evidenced in the moderate/high intake of carbohydrates, which in turn was linked to the fact that carbohydrates-rich food items from the 'cereal, roots and tubers' food group had the highest FVS when compared to other eight food groups. Carbohydrates-rich food items featured high in the list of top 20 most consumed food items. These findings are characteristic of eating behaviour of poverty stricken households. Work done by some authors in other provinces of South Africa also yielded similar results. That is, in Kwazulu-Natal Province [34,35], Gauteng Province [21], North-West Province [35,36], Limpopo Province [37], and Orange Free State Province [38].

Regarding protein, its intake was also moderate/high, with between $91.7 \%$ and $100 \%$ of the studied children having intake of this nutrient exceeding $67 \%$ of its RDA (Table 8). Canned fish and chicken were the two most consumed sources of protein. Other studies conducted in other South African provinces other than the Eastern Cape Province also found chicken to be the main source of protein [21,34-36,39]. The consumption of dried beans, which are cheaper alternative sources of protein, was not exploited. Other cheaper legumes such as soya and lentils were not consumed at all; apparently due to the entrenched eating habits in the study area. Such eating habits are common across the globe [40,41].

The intake of dietary fibre was not only low, but was concerning. This situation appeared a function of food processing which often resulted in refined food that has either low fibre content or none. Breakfast cereals which contained a considerable amount of dietary fibre were consumed in few households (11\%), because they were not easily financially accessible. Vegetables could not have provided a good source of dietary fibre, because a few of such vegetables (cabbage and spinach) were consumed, and their consumption was in very small quantities as shown in Table 7. Nevertheless, low intake of dietary fibre is a concerning problem in many parts of the country $[35,36]$ and in many developed and developing countries like South Africa [42].

The results of low intake of many minerals and vitamins that have been presented in the previous section of this paper are a reflection of poor consumption of fruits and vegetables, dairy products, eggs, legumes and various fleshy foods. On the other hand, the rather moderate to high intake of other minerals and vitamins is attributable to many factors. Firstly, bread/baking flour and maize meal had been fortified with selected minerals and vitamins in accordance with the South African Act No 54 of 1972 [43]. Fortification of maize meal was evident among the local newly established maize milling companies that have been funded through food security programmes of the Eastern Cape government. Fortified food items and their nutritive value appeared in the database of Food Finder III. Secondly, the wide 
spread households' consumption of food items such as dried beans, chicken, canned fish, dairy products, carrots, pumpkin / squash fruit and spinach appeared to have led to moderate to high intake of the minerals and vitamins that have been referred to above. However, as indicated earlier, these food items were not consumed in inadequate quantities (Table 7). Other than the fortification of staple food items, agri-business families need to grow and consume a wide range of vegetables, including those that are cheaper alternatives to fruit. Needless to say, in order to improve intake of all minerals and vitamins, diversification vegetable production and consumption should be applied. Inclusion of a legume other than dried beans in study population's diets is encouraged so as to improve the intake of nutrients that cannot be realized from rather expensive dairy products (e.g. calcium). Alfred Nzo District has unexploited potential to produce legumes which include soya. In addition to entertaining diversified crop/horticultural production, nutrition education need to be taken seriously in view of those nutrients whose intake was below $67 \%$ of their RDA in many households.

Regarding anthropometric nutritional status, South African communities are reportedly sandwiched between malnutrition, and overweight/obesity [44]. In the current study, majority of children had good nutritional status, because they had normal WAZ, HAZ and BMIZ. Very few had low nutritional status through being wasted and stunted. However, among children aged 5-8 years, the prevalence of underweight was $20 \%$, which is indicative of low nutritional status. In terms of the prevalence of various anthropometric conditions, this study found risk of overweight/overweight/ obesity a more threatening problem than malnutrition was. Possibly, the high prevalence of these anthropometric conditions was caused by high consumption of carbohydratesrich food items from the 'cereal, roots and tubers' food group and lack of physical activity.

\section{Conclusion}

This study showed that children from previously disadvantaged agri-business families enjoyed rather modest nutritional practices that were often characterized with consumption of low quantities of foods, deprivation of breakfast and some meals, high consumption of carbohydratesrich foods, and low consumption of fruits and vegetables. Food variety and dietary diversity scores which are indicative of nutritional status were low and conservatively high, respectively. The above indicators and feeding patterns, in general, had an effect on the intake of various nutrients under investigation. When compared with their RDA, the intake of these nutrients various, dietary fibre and carbohydrates intake being remarkably low to moderate/high, respectively. Most of the children had good nutritional status; in as far as their anthropometric dimensions are concerned. However, the creeping problem of overweight/obesity was concerning, while stunting and wasting were at low levels.
Nutritional status was found to be a function of farm and non-farm income, expenditure on food, and educational status of caregivers. In order to improve the children's nutritional status, this study recommended nutritional education among the caregivers, and diversification and intensification of farming practices in agri-businesses. Areas for future research were also recommended. These included an investigation into the standard procedure(s) and method(s) to be used in assessing nutrition security/nutritional status. Currently, many smallholder farming families are declared food and nutrition insecure by virtue of being previously disadvantaged, and as such the awarding of government production subsidies is based on this historical misfortune. There is also a need to extend similar research to other provinces of South Africa and to SADC. Lastly, future research work should be done in establishing the nutrition security/nutritional status of families of relatively bigger and well-established agri-business owners/managers.

\section{References}

1. Stats SA (2016) Community survey, Stats SA, Pretoria, South Africa.

2. Food and Agriculture Organization of the United Nations (1996) World food summit: Rome declaration on world food security and world food summit plan of action, FAO, Rome, Italy.

3. Misselhorn A, Hendriks S (2017) A systematic review of sub-national food insecurity research in South Africa: missed opportunities for policy insights. PLosONE 12(8): e01822399.

4. Monde N (2003) Household food security in rural areas of central Eastern Cape: The case of Guquka in Victoria East and Koloni in Middledrift districts, University of Fort Hare, Alice, South Africa.

5. Dirwayi TP (2010) Application of the sustainable livelihoods framework to the analysis of the provincial growth and development plan of the Eastern Cape: a case study of the Massive Food Production Programme in Nkonkobe Municipality and Buffalo City Municipality, University of Fort Hare Alice, South Africa.

6. Tregurtha $\mathrm{N}$ (2012) Inequality and economic marginalisation: review of the Eastern Cape's Siyakhula/Massive Maize Project. Trade and Industrial Policy Strategies, Pretoria, South Africa.

7. Ndhleve S, Musemva L, Zhou L (2013) Household food security in a coastal rural community of South Africa: status, causes and coping strategies. African Journal of Agricultural and Food Security 1(1): 1520.

8. Oni SA, Maliwichi LL, Obadira OS (2010) Assessing the contribution of smallholder irrigation to household food security in comparison to dryland farming in Vhembe District of Limpopo Province, South Africa. African Journal of Agricultural Research 6(10): 2188-2197.

9. Kahsay S, Mulugeta M (2014) Determinants of rural household food security in LaelayMaichewWoredaTigray, Ethiopia. African Journal of Agriculture and Food Security 2(1): 106-112.

10. Abate T, Shiferaw B, Menkir A, Wegary D, Kebede Y et al. (2015) Factors that transformed maize productivity in Ethiopia. Food Security 7(5): 965-981.

11. Pingali P (2015) Agricultural policy and nutrition outcomes - getting beyond the pre-occupation with staple grains. Food Security 7(3): 583591.

12. Oldewage-Theron WH, Kruger R (2008) Food variety and dietary diversity as indicators of the dietary adequacy and health status of an elderly population in Sharpeville, South Africa. J Nutr Elder 27(1-2): 101-133. 
13. Wellman NS, Kamped BJ (2008) Nutrition and ageing. In: Mahan LH \& Krauer ESS (Eds.), Food, nutrition and diet therapy. (12 $2^{\text {th }}$ edn), W B. Saunders Company, Philadelphia, Pennsylvania, USA.

14. Institute of Medicine (2003) Dietary reference intake, National Academy Press, Washington, D.C, USA.

15. Wenhold F, Faber M (2012) Nutritional status of South African and strategies to address malnutrition, In: Oelofse A, Van Averbeke W (Eds.), Nutritional value and water use of African leafy vegetables for improved livelihoods, Government Printer, Department of Agriculture, Forestry and Fisheries, Pretoria, South Africa.

16. World Health Organization (1995) Physical status: the use and interpretation of anthropometry, technical report series No. 854 WHO: Geneva, Switzerland.

17. Beukman TL (2005) The effect of selected variables on leadership behavior within the framework of a transformational organisation, University of Pretoria, Pretoria, South Africa.

18. Nordstokke DW, Zumbo BD, Cairns S, Saklofske DH (2011) The operating characteristics of the non-parametric Levene test for equal variances with assessment and evaluation data. Practical Assessment Research and Evaluation 16(5): 1-8.

19. Eastern Cape Socio-economic Consultative Council (2014) Alfred Nzo District Municipality socio-economic profile, Eastern Cape Socioeconomic Consultative Council, East London, South Africa.

20. Department of Trade and Industry (1996) NationalSmall Business Act. No. 92 of 1996, Government Printer, Pretoria, South Africa.

21. Matla MTH (2008) The contribution of food access strategies to dietary diversity of farm worker households on Orange farm in the Fouriesburg District (RSA), University of Pretoria, Pretoria, South Africa.

22. Badari SAZ, Arcot J, Haron SA, Paim L, Sulaiman N et al. (2012) Food variety and dietary diversity scores to understand the food intake pattern among selected Malaysian households. Ecol Food Nutr 51(4): 265-299.

23. Ongosi AN, Gericke G, Mbuthia E, Oelofse A (2014) Food variety, dietary diversity and perceived hunger among lactating women (0-6 months post-partum) in low socio-economic area in Nairobi, Kenya. African Journal of Food, Agriculture, Nutrition and Development 14(2): 8663 8675 .

24. Hahoney CR, Taylor HA, Kanarek RB, Samuel P (2005) Effect of breakfast composition on cognitive processes in elementary school children. Physiol Behav 85(5): 635-645.

25. Min C, Noh H, Kang KS, Sim HJ, Baik HW, et al. (2011) Skipping breakfast is associated with diet quality and metabolic syndrome risk factors of adults. Nutr Res Pract 5(5): 455-463.

26. Mekary RA, Giovannucci E, Cahill L, Willett WC, van Dam RM et al. (2013) Eating patterns and type 2 diabetes risk in older women breakfast consumption and eating frequency. Am J Clin Nutr 98(2): 436-443.

27. Kahleova H, Lloren JI, Mashchak A, Hill M, Fraser GE (2017) Meal frequency and timing are associated with changes in body mass index in adventist health study 2. J Nutr 147(9): 1722-1728.

28. Ruel M (2002) Is dietary diversity an indicator of food security or dietary quality? A review of measurement issues and research needs.
Food Consumption and Nutrition Division Discussion Paper No. 140. International Food Policy Research Institute, Washington, D.C., USA.

29. Burchi F, DeMuro P (2016) From food availability to nutritional capabilities: advancing food security analysis. Food Policy 60: 10-19.

30. Kunwar R, Pillai PB (2002) Impact of education of parents on nutritional status of primary school children. Med J Armed Forces India 58(1): 38-432.

31. Abuya BA, Ciera J, Kimani-Murage E (2012) Effect of mother's education on child's nutritional status in the slums of Nairobi. BMC Pediatrics 12(8): 2-10.

32. Alalaq H, Katuli S, Beeson L, Ormsby G, Cordero-MacItyre Z (2014) Parents education and children nutritional status aged 2 to 5 in Zambia. The FASEB Journal 28(1):1-12.

33. Von Fintel D, Pienaar L (2016) Small-scale farming and food security: the enabling role of cash transfers in South Africa's former homelands, University of Stellenbosch, Stellenbosch, South Africa.

34. Silangwe BN (2012) Nutritional status and dietary intake of adolescents in Mandlenkosi high school - Lindelani, Durban University of Technology, Durban, South Africa.

35. Mchiza ZJ, Steyn NP, Hill J, Kruger A, Schönfeldt H, et al. (2015) A review of dietary surveys in the adult South African population from 2000 to 2015. Nutrients 7(9): 8227-8250.

36. Rossouw CR (2005) Eating habits and nutrient intakes of 10-15 year old children in the North West Province, North-West University, Potchefstroom, South Africa.

37. Mushaphi LF (2011) Impact of a nutrition education programme on the nutritional status of children aged 3 to 5 years, and the nutritional practices and knowledge of their caregivers in rural Limpopo Province, South Africa, University of the Free State, Bloemfontein, South Africa

38. Mofokeng MJ (2013) Nutritional status and dietary intake patterns of children aged 7-13 years in Qwaqwa, Vaal University of Technology, Vanderbijlpark, South Africa.

39. Govender T (2011) Analysis of the nutritional status and dietary intake data of a group of elderly at a day and frail care centre in Verulam,Durban University of Technology, Durban, South Africa.

40. Ganasegeran K, Al-Dubai SAR, Qureshi AM, Al-abed AAA, Rizal AM, et al. (2012) Social and psychological factors affecting eating habits among university students in a Malaysian medical school: a crosssection study. Nutrition Journal 11(48): 183S-188S.

41. Coelho LG, Cândido APC, Machado-Coelho GLL, de Freitas SN (2012) Association between nutritional status, food habits and physical activity level in school children. J Pediatr (Rio J) 88(5): 406-412.

42. Vitolo MR, Campagnolo PDB, Gama CM (2007) Factors associated with risk of low dietary fiber intake in adolescents. Journal de Pediatria 83(1): 47-52.

43. Department of Health (1972) Foodstuffs, cosmetics and disinfectants, Act No. 54 of 1972,Government Printer, Pretoria, South Africa.

44. Van Graan AE, Bopape M, Phooko D, Bourne DL, Wright HH (2013) Drink lots of clean, safe water: a food-based dietary guideline for South Africa. South African Journal of Clinical Nutrition 26 (Supplement) S77-S86. 
This work is licensed under Creative Commons Attribution 4.0 License

DOI: 10.19080/NFSIJ.2018.06.555682
Your next submission with Juniper Publishers will reach you the below assets

- Quality Editorial service

- Swift Peer Review

- Reprints availability

- E-prints Service

- Manuscript Podcast for convenient understanding

- Global attainment for your research

- Manuscript accessibility in different formats

( Pdf, E-pub, Full Text, Audio)

- Unceasing customer service

Track the below URL for one-step submission https://juniperpublishers.com/online-submission.php 